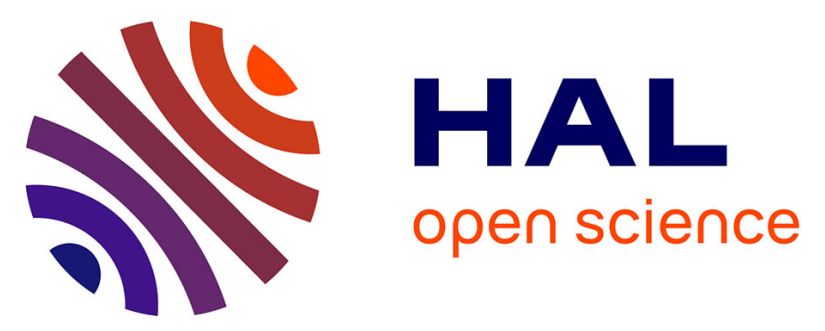

\title{
Evolution of cherries texture in brine: Impact of harvest conditions during long-time storage
}

Wael Wahib Mahmoud, Jean Francois Maingonnat, Ulrich Fleury, Mohamed El-Maataoui, Catherine M.G.C. Renard

\section{- To cite this version:}

Wael Wahib Mahmoud, Jean Francois Maingonnat, Ulrich Fleury, Mohamed El-Maataoui, Catherine M.G.C. Renard. Evolution of cherries texture in brine: Impact of harvest conditions during longtime storage. LWT - Food Science and Technology, 2017, 75, pp.243-250. 10.1016/j.lwt.2016.08.059 . hal-02626695

\section{HAL Id: hal-02626695 \\ https://hal.inrae.fr/hal-02626695}

Submitted on 26 May 2020

HAL is a multi-disciplinary open access archive for the deposit and dissemination of scientific research documents, whether they are published or not. The documents may come from teaching and research institutions in France or abroad, or from public or private research centers.
L'archive ouverte pluridisciplinaire HAL, est destinée au dépôt et à la diffusion de documents scientifiques de niveau recherche, publiés ou non, émanant des établissements d'enseignement et de recherche français ou étrangers, des laboratoires publics ou privés. 


\title{
Evolution of cherries texture in brine: Impact of harvest conditions during long-time storage
}

\author{
Wael Wahib a, b, c, d, *, Jean François Maingonnat a, b, Ulrich Fleury ${ }^{\mathrm{d}}$, \\ Mohamed El-Maataoui ${ }^{\mathrm{c}}$, Catherine M.G.C. Renard ${ }^{\mathrm{a}, \mathrm{b}}$ \\ a INRA, UMR408 SQPOV, Avignon, France \\ b Université d'Avignon, UMR408 SQPOV, Avignon, France \\ ${ }^{\mathrm{C}}$ Université d'Avignon, UMR Qualisud, Avignon, France \\ ${ }^{\mathrm{d}}$ Aptunion Industrie, Apt, France
}

Keywords:

Prunus avium $\mathrm{L}$.

Firmness

Candied cherries

Brine

Cytohistology

Cell wall

\begin{abstract}
A B S T R A C T
Texture is a primary quality attribute of brined sweet cherries (Prunus avium L.) and its preservation is a major objective for candying industry. In order to identify the harvest factors influencing textural changes during long period brine storage, different itineraries were applied: harvest at two different maturity stages, treatment or not with ethephon, manual or mechanical harvest, removal or not of peduncles. The cherries were immersed in brine and examined over a 12-months period for firmness, calcium and total soluble solids diffusion and cytohistological remodelling. Mechanical harvesting, harvest at late maturity stage and storage with peduncle decreased firmness while ethephon treatment had no effect. However, only presence or absence of peduncles influenced salt and total soluble solids diffusion, suggesting that peduncle removal promotes osmotic exchanges.

Brine storage led to a texture gain in the first two months in most cases compared to fresh cherries, as confirmed by a beneficial reshuffle at cytohistological level. This explains why it can allow storage of cherries for candying over the whole duration between two harvest seasons.
\end{abstract}

\section{Introduction}

Sweet cherries (Prunus avium L. cv. Napoléon) produced in Vaucluse (South France) are mainly intended for processing to glacé cherries, represented 10.000 tons of final product, with $70 \%$ destined for more than 60 countries. They must be harvested within a short time (3-4 weeks) and are then stored in brine for candying all along the year. The narrow window of harvesting prompted growers to adopt mechanical methods based on the use of ethephon (2-chloroethyl phosphonic acid) and harvesting at an earlier stage. The ethylene released by Ethephon induces a decrease of the pedicel-fruit retention force in sweet cherry (Smith \& Whiting, 2007). This is mediated by its binding to receptor sites

* Corresponding author. INRA, UMR408 SQPOV, Avignon, France. - Université d'Avignon, UMR408 SQPOV, Avignon, France. - Université d'Avignon, UMR Qualisud, Avignon, France. - Aptunion Industrie, Apt, France.

E-mail addresses: wael.wahib@aptunion.com (W. Wahib), jean-francois. Maingonnat@avignon.inra.fr (J.F. Maingonnat), ulrich.fleury@aptunion.com (U. Fleury), mohamed.elmaataoui@univ-avignon.fr (M. El-Maataoui), catherine renard@avignon.inra.fr (C.M.G.C. Renard). that initiates a signal transduction leading to acceleration of cellwall degrading enzymes and cell death in the abscission zone (Estornell, Agusti, Merelo, Talon, and Tadeo (2013); Hall., Shakeel, \& Schaller (2007)). In the case of cherries, approximately $80 \%$ fruits fall without peduncle. However, this harvesting method is not a rule and manually harvested cherries still represent $20 \%$ of total quantity delivered to industry (Ulrich Fleury, personal communication).

Between harvest and candying, cherry fruits are stored in brine containing sulfur dioxide and calcium salts. Acidity and sulphites protect fruit from microorganism proliferation due to $\mathrm{SO}_{2}$ antiseptic effects (Dupuy, 1959; Julien, 1972). Calcium salts act on cherries firmness, as also noted to improve texture for pickled cucumbers (Hudson \& Buescher, 1985). Sulfur dioxide and calcium are directly related to brined cherry quality. Improper use of these chemicals may result in cherries that are soft, poorly bleached, or spoiled due to fermentation (Payne, Beavers, Cain, \& Station (1969)). Atkinson and Strachan (1962) pointed out other advantages of sulfur dioxide as a preservative. It is inexpensive and provides a quick method of handling large quantities of fruit. The 
product may be placed in bulk containers for shipment, and the preservative is effective for a sufficient period of time to allow for storage and remanufacture. In addition, most of the sulfur dioxide can be removed easily and inexpensively before candying, so that this allergen is absent (Aptunion, internal analysis) in the glacé cherries. Moreover, storing for a long period without loss of fruit quality is one of industries objectives.

Firmness loss during fruit development is associated with cellwall polysaccharide turnover (Brummell \& Harpster, 2001). Cherry cell walls are modified in harvesting, whether after chemical ethephon treatment (Batisse, Coulomb, Coulomb, and Buret (1998)) or natural ripening-overripening mechanism (Batisse, Filslycaon, and Buret (1994)) leading to softness. Some of the genotypic variations in fruit firmness have been linked with differences in the patterns of cell-wall disassembly. For example, Cheol, Toivonen, Wiersma, and Kappel (2002) reported that soft varieties present lower total cell wall contents in fresh fruit. Taillan, Ambid, Pech, and Raynal (1992) demonstrated that pectic fractions were the main cell wall component modified during cherries storage in aluminium or calcium brines; fruits stored in calcium brine present a better firmness than in aluminium brine leading industry to continually improve brine formulation to increase the quality of stored fruits.

However, other factors have been reported to be important modulators for cherry post harvest behaviour. Richardson et al. (1998) reported that some harvest factors are susceptible to affect sweet cherries $P$. avium cv. Royal Ann texture, such as machine factors (pattern of tree shaking, duration of shakes, etc.), climatic conditions, crop loads, tree sizes or their spacing. Since this early work, no studies have attempted to evaluate the consequences of other harvest itineraries on the evolution of the quality of cherries in brine. Understanding the impact of the harvest conditions on cherry texture evolution during storage is of major importance for the industry. In the present study, evolution of firmness during brine storage was quantified according to the fruits maturity stage, the harvesting method, the ethephon application and the peduncle presence. Cytohistological investigations have been performed to follow the gross structural alterations during storage in brine.

\section{Materials and methods}

\subsection{Plant material}

Fruit of sweet cherry (Prunus avium L., cv. Napoléon) for industry were harvested in Provence (Lagnes $43^{\circ} 53^{\prime} 39^{\prime \prime} \mathrm{N}$ and $5^{\circ} 06^{\prime} 55^{\prime \prime}$ ) in June 2013. Table 1 summarizes the different treatments and harvest conditions. Ethephon (PRM12, Bayer S.A.S, Lyon, France) was applied at $0.36 \mathrm{~g} \mathrm{~L}^{-1}$ on vigorous trees [conditions (1) and (2)], by high humidity and $20{ }^{\circ} \mathrm{C}$ (standard treatment). Untreated trees were also included in the study (conditions (3) and (4)). Cherries were picked at 10 "early" and 20 "late" days after treatment with ethephon corresponding to the beginning and end of the harvest. The fruits were harvested mechanically [condition (2)] or manually (1), (3) and (4) then immediately immersed in brine tanks (Type

\section{Table 1}

: Summary of the different treatments and harvest conditions for the different sweet cherry samples. Ethephon was applied at $0.36 \mathrm{~g} \mathrm{l}^{-1}$; mechanical harvest stored in industrial container and manual harvest stored in bucket for practically. Each sample was picked at to maturity stage "early" and "late".

\begin{tabular}{lllll}
\hline Sample & 1 & 2 & 3 & 4 \\
\hline Ethephon & + & + & - & - \\
Peduncle & + & - & + & - \\
Harvest method & Manual & Mechanical & Manual & Manual \\
Container $\left(\mathrm{m}^{3}\right)$ & 0.025 & 3 & 0.025 & 0.025 \\
\hline
\end{tabular}

Aptunion, Apt, France) for storage with 50/50 ratio fruit/brine. Fruits (1) and (3) were stored in brine with their peduncle and fruits (2) and (4) without peduncle (Table 1 ).

Samples were taken at $0,2,5,8$, and 15 days and at $1,2,3,4,5,6$, $7,8,10$ and 12 months in brine.

\subsection{Fruit texture characterization}

For each treatment, 62 cherries (randomly chosen) were placed in holes, with the peduncle scar on top (Fig. 1). They were pitted with a texture analyser TA Plus (Ametek, Lloyd Instruments Ltd, Fareham, UK) using an $8 \mathrm{~mm}$ diameter probe moving at $20 \mathrm{~mm} \mathrm{~s}^{-1}$ for a course of $40 \mathrm{~mm}$ after first contact. The maximum load (Newton) during pitting, captured by a $250 \mathrm{~N}$ load cell, is our criterion to define the texture quality. It was chosen as the texture test as it is representative of the actual process, pitting being a critical point in the processing to glacé cherries, and presented a good correlation with a compression test such as routinely applied to other fruits, e.g. in Grotte, Duprat, Loonis, and Pietri (2001); Missang, Maingonnat, Renard, and Audergon (2011).

\subsection{Physico-chemical characterizations}

The total soluble solids (TSS) or Brix were measured in the brine with an ATAGO PR-1 Digital Refractometer (Atago Co., LTD, Tokyo, Japan). Indeed, brine TSS is complementary to fruit TSS due to the diffusion phenomenon that leads to an equilibrium state.

Calcium concentration in the brine was measured by Atomic absorption spectroscopy on a Varian AA 55 (Agilent technologies, Santa Clara, USA) equipped with an acetylene/nitrous oxide burner.

\subsection{Microscopy}

Cytohistological analyses were performed using tissue samples excised from median part of fruits going from exocarp to endocarp (Fig. 2). Immediately after excision all specimens were immersed in fixative solution consisting of $10 \%$ Acetic acid $10 \%$ Formalin and $80 \%$ Ethanol. To promote good penetration of the fixative product samples were subjected to vacuum for $20 \mathrm{~min}$. After $48 \mathrm{~h}$ fixation at room temperature, the specimens were rinsed in distilled water and stored in $70 \%$ ethanol until required. They were then dehydrated in a graded ethanol series (80-100\%) and embedded in methacrylate resin (Kit Technovit 7100, Heraeus-Kulzer GmbH,

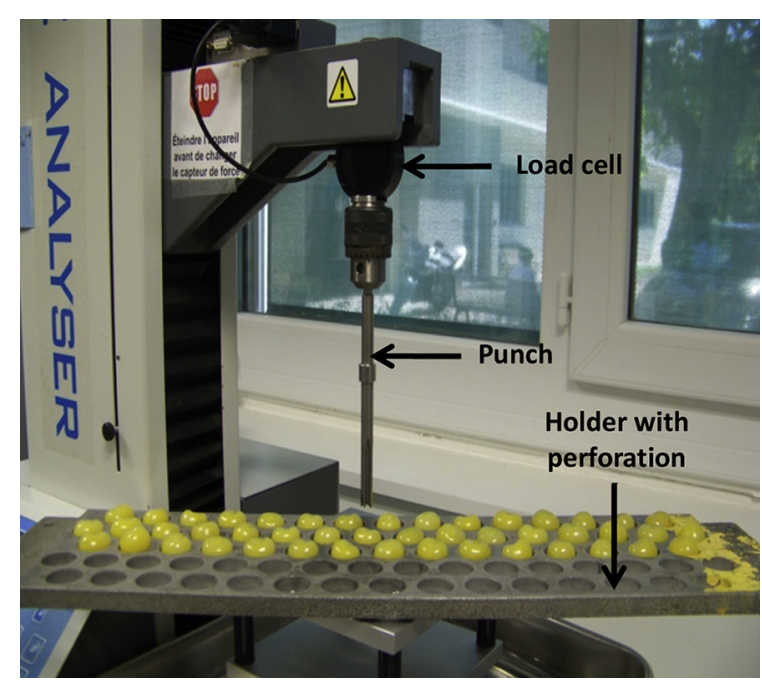

Fig. 1. Sweet cherry disposition and orientation for firmness measurements. 
Version définitive du manuscrit publiée dans / Final version of the manuscript published in :

LWT - Food Science and Technology (2017), Vol. 75, p. 243-250, DOI: 10.1016/j.Iwt.2016.08.059

Journal homepage : www.elsevier.com/locate/lwt

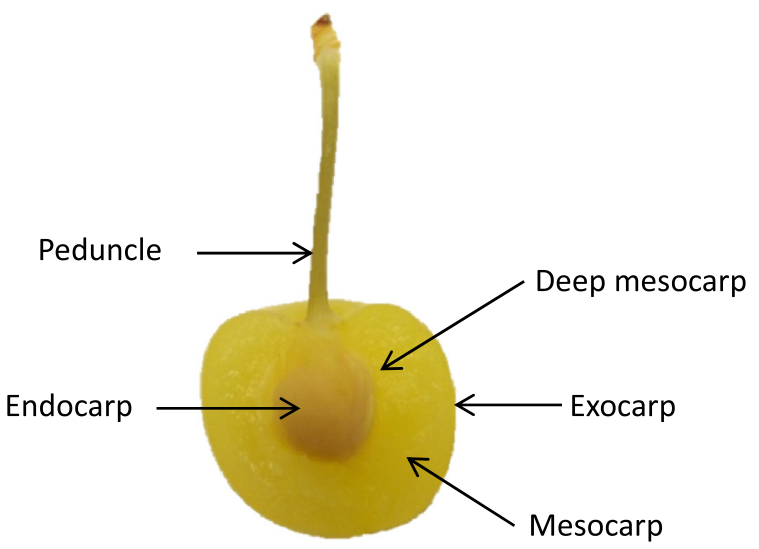

Fig. 2. Cherry fruit pericarp with the 3 zones of cytohistological interesting: exocarp, middle mesocarp and deep mesocarp.

Wehrheim, Germany). Sections ( $3 \mu \mathrm{m}$ thickness) were serially cut using a retraction microtome (Supercut 2065; Reichert-Young, Wien, Austria), and collected on microscope slides. They were stained to visualise polysaccharides and proteins using periodic acid-Schiff's reagent and naphthol blue-black procedures, respectively (El Maâtaoui \& Pichot, 1999). Observations were performed using Leica DMR photomicroscope equipped for brightfield,

Firmness (N)
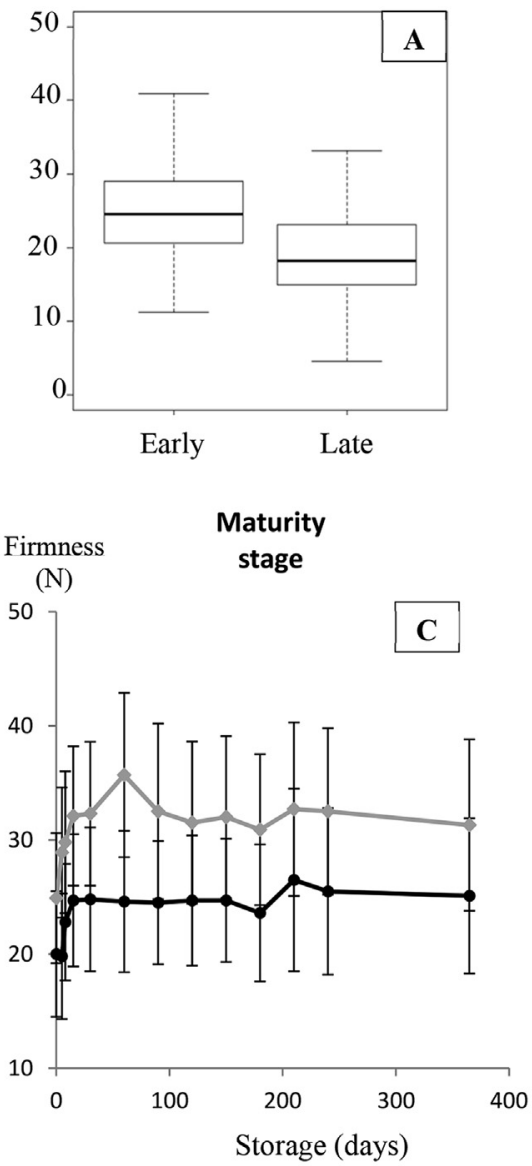

darkfield, phase contrast and UV illuminations. Images were captured using Leica DFC 300 FX digital camera and processed using LAS software (Leica, Wetzlar, Germany). At least 6 fruits were analysed per treatment.

\subsection{Statistics}

All statistics were performed using $R$ i386 3.1.2 software ( $R$ Foundation for Statistical Computing, Vienna, Austria). Prior to analysis data were tested using Shapiro-Wilk normality test to verify the distribution. Mean and Sd were calculated and one-way analysis of variance (ANOVA) and the Tukey post-hoc test were applied to verify the significance of differences between firmness, TSS and calcium levels in fruits from different harvest conditions.

\section{Results and discussion}

\subsection{General evolution of texture during storage}

During storage in brine, evolution of cherry texture was characterized by a first stage of rapid increase in firmness, up to about 10 days. This was followed by a second stage (10 days -2 months) of texture stabilisation, and between 2 and 12 months texture remained constant or showed limited decreasing trend (Fig. 3C and D). Storage in brine thus increased fruit firmness with a maximum reached in about 2 months. Thereafter comparison will concern only D0, D8, M2 and M12 conservation stages as those present

Firmness (N)

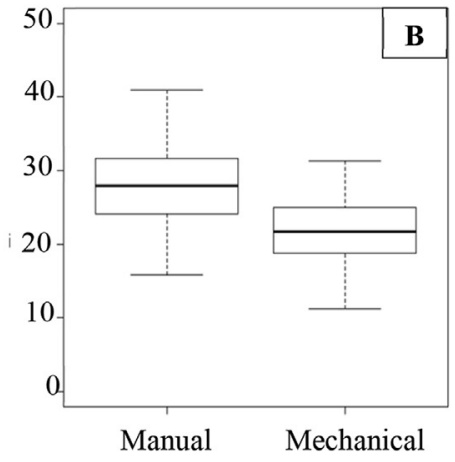

Harvest

type

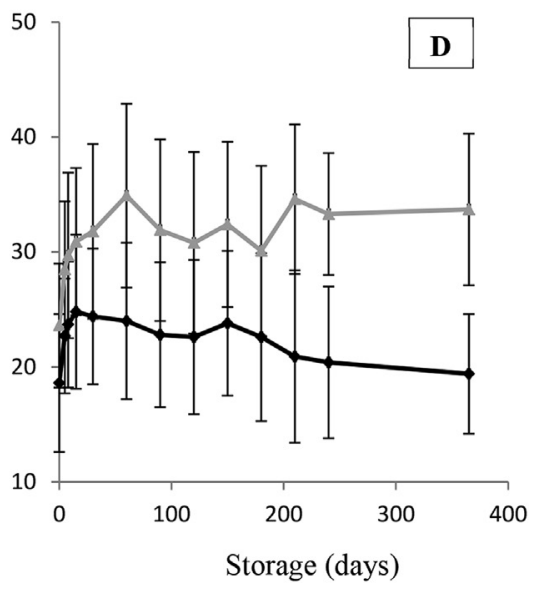

Fig. 3. Initial cherry texture according to A maturity stage and B harvest type and their texture evolution during storage in brine $\mathrm{C}$ according to maturity stage: $=\bullet$ early, $\rightarrow \subset$ late and D harvest type: $\rightarrow$ manual, $\rightarrow$ mechanical. Each point corresponds to 248 randomly selected fruits. Average and standard deviation are represented. 
characteristics points during cherries evolution in brine. This can be compared to the short shelf life of fresh cherries, with both texture loss and material degradation. For example Wei, Qi, Guan, and Zhu (2011) maintained firmness for 30 days after 1methylcycloproprene (1-MCP) treatment combined with $0{ }^{\circ} \mathrm{C}$ storage and 8 days for untreated sweet cherry 'Summit'. Preservation effects in sulfur dioxide brine are mainly due to the inhibition of deleterious enzymatic activity thanks to brine and by the calcium complexation in different fruit tissues. Conservation by brineprocess confers a stable firmness to pickled capers (Capparis spp.) in brine (Ozcan \& Akgul, 1999) and allows improving texture in first stage and stabilization for some months in pickled cucumbers (Bell \& Etchells, 1961; Hudson \& Buescher, 1985).

\subsection{Maturity stage and harvest method}

The cherries picked at different maturity stages had different initial firmness: fresh "early" cherries presented a median firmness of $25 \mathrm{~N}$ at harvest, and "late" fruit $18 \mathrm{~N}$ (Fig. 3A). They reached $35 \mathrm{~N}$ for "early" and $25 \mathrm{~N}$ for "late" after 2 months and firmness then remained constant over one year storage (Fig. 3C). Indeed maturation is characterized by loss of firmness, as has been reported by Batisse et al. (1994) and Filslycaon and Buret (1990) for sweet cherries including 'Napoléon' cultivar. The initial loss observed here was of $38 \%$ of the firmness, with a mean difference of $6-7 \mathrm{~N}$ that persisted throughout brine storage but the gap becomes $19 \%$ of the firmness after 12 months.

Harvesting modalities had an impact on initial texture ( $25 \mathrm{~N}$ for manual, $18 \mathrm{~N}$ for mechanical) (Fig. 3B), at 2 months (35 $\mathrm{N}$ for manual, $24 \mathrm{~N}$ for mechanical), but more important also on texture evolution after 1 year storage in brine (Fig. 3D). Mechanically harvested cherries showed a trend for texture loss reaching $19 \mathrm{~N}$ after 12 months, while the texture of manually harvested cherries remained stable at about $34 \mathrm{~N}$ after one year. The difference in firmness thus increased to reach $15 \mathrm{~N}$, which was significant and corresponded to the quality differential observed industrially, with soft fruit and increased loss for mechanically harvested cherries after prolonged storage. However they remained above the limit of processability, which has been assessed at $17 \mathrm{~N}$. The mechanical harvest, in spite of its great advantages in cost and speed, was deleterious to fruit quality, probably by increasing mechanical damage and decreasing fruit firmness, as also observed by Timm and Guyer (1998) for tart cherries. Storing in brine over a long period conferred a texture gain, improving effectively the fruit quality for a manual harvest whereas the gain was minimal after a mechanical harvest with fruits that remained above the limit of processability.

\subsection{Ethephon application}

Mechanized harvest is dependent on ethephon application. Ethephon application had a slight impact on initial texture $(24 \mathrm{~N}$ for untreated, $28 \mathrm{~N}$ for treated) (Fig. 4) i.e. on average a gain of about $15 \%$. This effect was at the opposite to what Smith and Whiting (2009) reported, i.e. ethephon application leads to a decrease of firmness by about 20\% in both "Chelan" and "Bing" fresh cherries harvested 22 days after ethephon treatments. Initial firmness difference disappeared during brine soaking (31 $\mathrm{N}$ at 2 months for both batches) and cherry had almost the same firmness ( $30.5 \mathrm{~N}$ for untreated against $29.5 \mathrm{~N}$ for treated) after 12 months. Ethephon application had a positive impact on fresh cherries firmness but brine storage led to texture equalization. Ethephon is known to have different consequences on texture depending on plant species; it decreases firmness in both kiwifruit and muskmelon (Yamaguchi, Hughes, Tyler, Johnson, \& May, 1977; Zhang, Li, Liu, Song, \& Liu, 2012), does not impact texture in cucumber (Miller \&

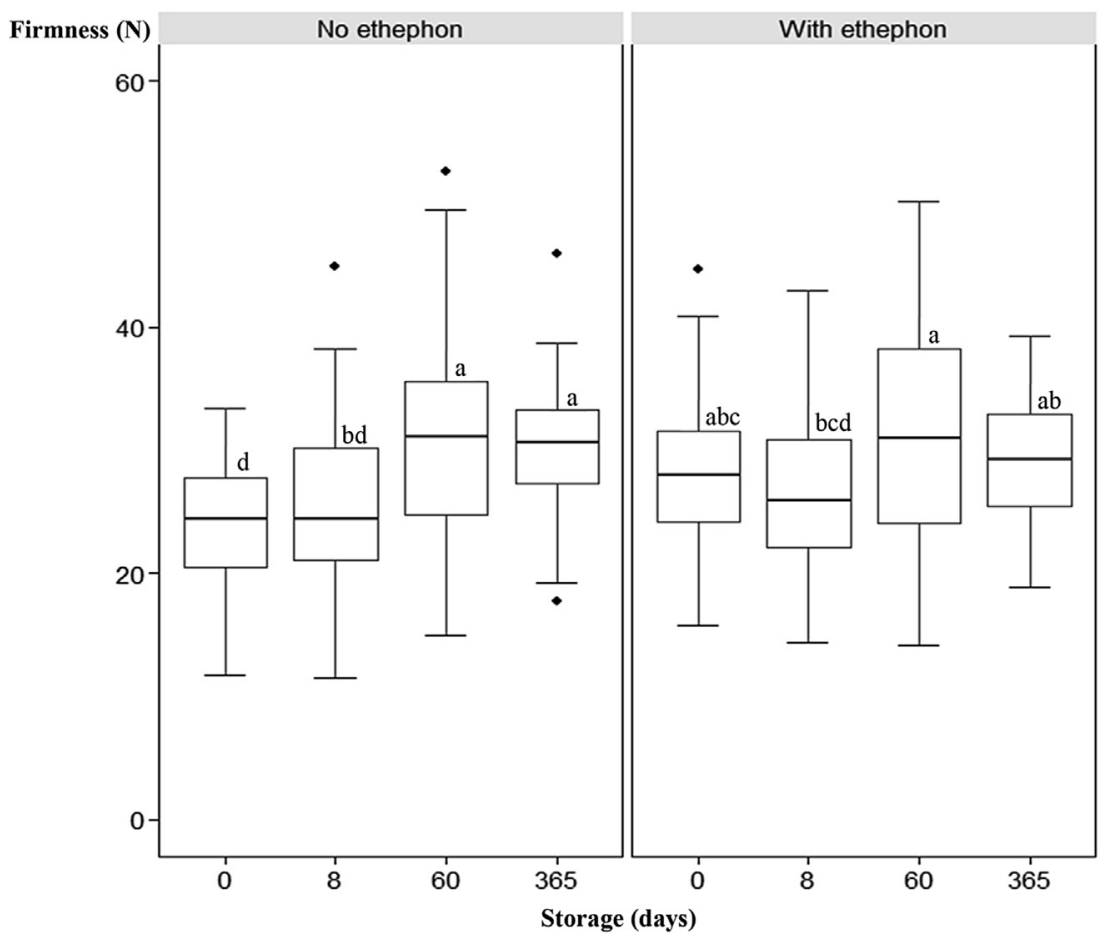

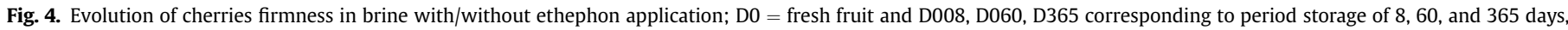

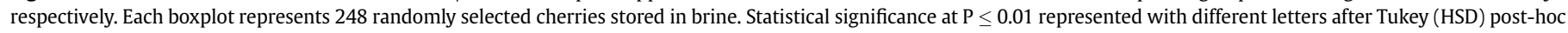
test. 
Version définitive du manuscrit publiée dans / Final version of the manuscript published in :

LWT - Food Science and Technology (2017), Vol. 75, p. 243-250, DOI: 10.1016/j.Iwt.2016.08.059

Journal homepage : www.elsevier.com/locate/lwt

Lower, 1972) or induces a better ripening of fruits with uniform colour, pleasant flavour, desirable firmness and acceptable sensory quality in guava (Mahajan, Gagandeep, \& Dhatt, 2008).

\subsection{Peduncle effect}

Removing peduncle before soaking in brine improved texture of fruits. Starting from the same firmness level $(23 \mathrm{~N})$, cherries without peduncle presented higher firmness than integrals cherries ones immersed in brine ( $29 \mathrm{~N}$ and $24 \mathrm{~N}$, respectively) after 8 days (Fig. 5). Then, the firmness reached $34 \mathrm{~N}$ against $31 \mathrm{~N}$ after 2 months storage and between 2 and 12 months texture remained constant with the same gap. This suggests that absence of peduncle leads to fruit with a better texture. The peduncle-abscission zone might be a preferential circuit of exchange between cherries and brine salts. The pedicel of a sweet cherry fruit is a useful indicator of its postharvest freshness (Drake \& Elfving, 2002; Sekse \& Lyngstad, 1993; Wani, Singh, Gul, Wani, \& Langowski, 2014). Although studies have been carried out on molecular composition of peduncle (Khalid, Gellert, Szendrei, \& Duddeck, 1989) and transpiration mechanism (Athoo, Winkler, \& Knoche, 2015) in sweet cherries or abscission and physical zone separation in rabbiteye blueberry (Vashisth \& Malladi, 2013), little is known about impact of peduncle removal. Here we show for the first time that peduncle removal had a marked effect on texture of cherry during brine storage leading to improved fruit texture, mostly by increasing the firmness gain between crop days and 2 months.

Table 2 summarizes the variations in firmness in our experimental system. It appears that the best combination was a manual harvesting thus not requiring ethephon, in the early maturation stage and immersing in brine without peduncle. However, this is not practical economically as mechanical harvest is highly effective in terms of cost and rapidity. Storage in brine promotes textural changes in cherries, even mechanically harvested, thus allowing their utilisation for processed candied-fruits until the next crop year.

\subsection{TSS and calcium evolution in brine}

During storage in brine, the sugars and organic acids that constitute most of the TSS of sweet cherries diffuse to the brine by osmotic phenomenon and, inversely, the brine components like calcium diffuse from brine to sweet cherries (Karel, 1975; Taillan, 1991). Accordingly, the measures were performed only in brine, assuming the remainder was in the fruits. The cherries without peduncle released more TSS after 8 and 60 days in brine than those immersed with peduncle. After 1 year storage, TSS in brine was higher for the fruits without peduncle (Fig. 6A). This difference in TSS content of the brine after 1 year (i.e. equilibration complete) starting from identical initial fruit $\left(16.5^{\circ} \mathrm{B}\right)$ and brine (same batch) soluble solids might be an artefact from fruit packing in the bins. Indeed, while a 50/50 ratio (weight/weight) was initially aimed for, fruits with peduncle occupied more volume per weight so that more brine had to be added to cover them.Calcium evolution in the brine (Fig. 6B) was faster for cherries without peduncle; after 8 days cherries without peduncle had absorbed about $10 \%$ more calcium than cherries with peduncle.

Calcium is well known to enhance texture of fruit and particularly of fruit stored in brine, as has been studied for pickled cucumbers (Howard \& Buescher, 1990; McFeeters, 1985). It limits the softening of pickles during heating or storage under different conditions (Tang \& McFeeters, 1983). The impact of calcium on texture is due to formation of calcium cross-links between pectin molecules in the cell wall (Van Buren, 1979). Garcia, Brenes, and Garrido (1994) reported that the monovalent sodium ions $\mathrm{Na}^{+}$ does not show any action on firmness while calcium $\mathrm{Ca}^{2+}$ improves

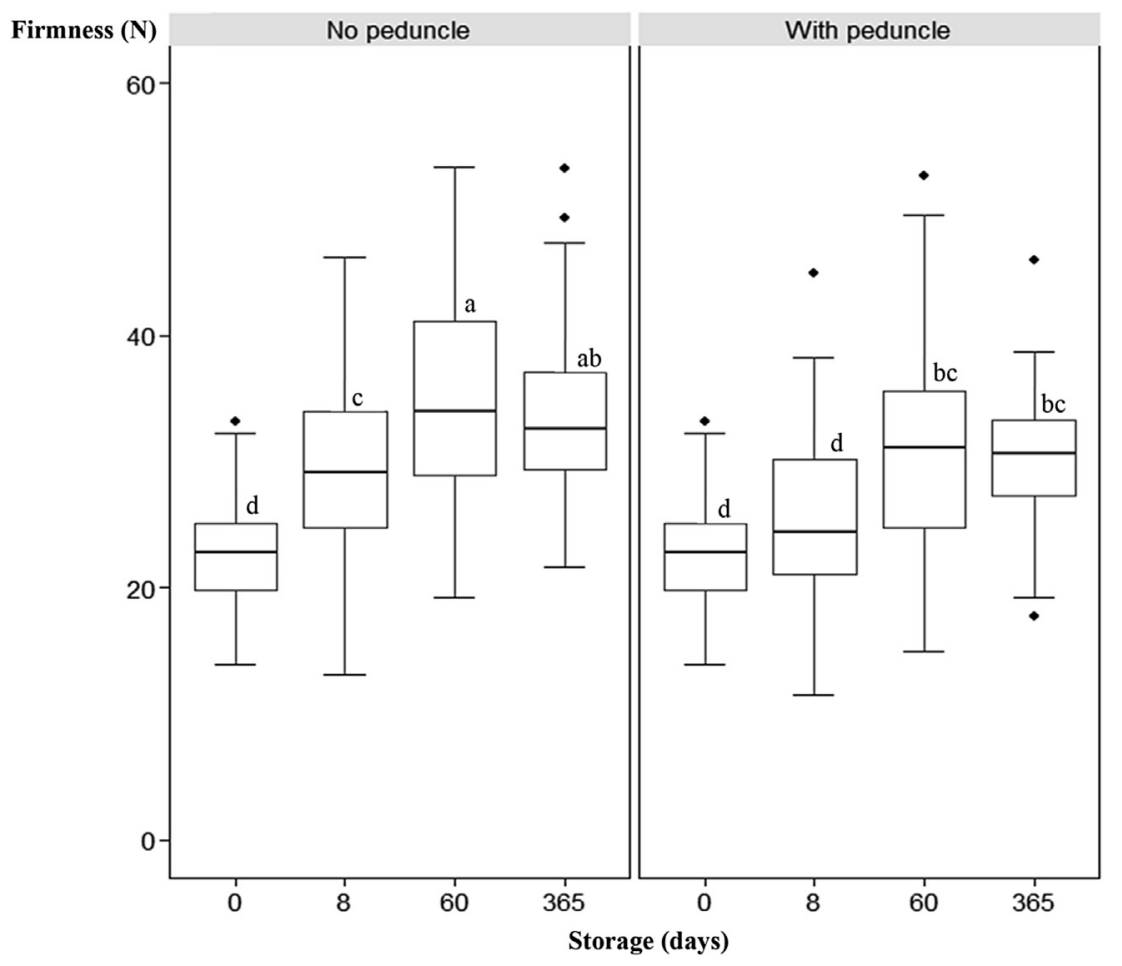

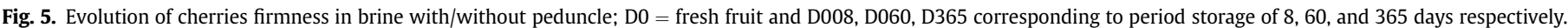

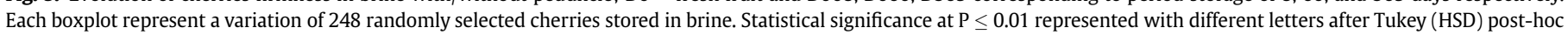
test. 
Version définitive du manuscrit publiée dans / Final version of the manuscript published in :

LWT - Food Science and Technology (2017), Vol. 75, p. 243-250, DOI: 10.1016/j.Iwt.2016.08.059

Journal homepage : www.elsevier.com/locate/lwt

Table 2

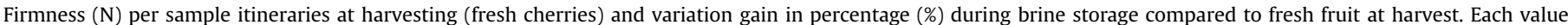
represents an average (bold text) of 62 randomly selected fruits and standard deviation is represented $( \pm)$.

\begin{tabular}{|c|c|c|c|c|c|c|c|}
\hline Maturity stage & Harvest method & Ethephon & Peduncle & Fresh cherries & 15 days in brine & 2 months in brine & 1 year in brine \\
\hline \multirow[t]{4}{*}{ Early } & Manual & Yes & $\mathrm{P}+$ & $\mathbf{2 8} \pm 4.9$ & $\begin{array}{l}34 \pm 5.1 \\
24 \%\end{array}$ & $\begin{array}{l}37 \pm 4.8 \\
34 \%\end{array}$ & $\begin{array}{l}30 \pm 3.4 \\
8 \%\end{array}$ \\
\hline & Mechanical & Yes & $\mathrm{P}_{-}$ & $22 \pm 4.2$ & $\begin{array}{l}\mathbf{2 9} \pm 5 \\
29 \%\end{array}$ & $\begin{array}{l}\mathbf{2 8} \pm 3.8 \\
27 \%\end{array}$ & $\begin{array}{l}\mathbf{2 2} \pm 4.2 \\
0 \%\end{array}$ \\
\hline & Manual & No & $\mathrm{P}+$ & $24 \pm 4.7$ & $\begin{array}{l}32 \pm 4.9 \\
31 \%\end{array}$ & $\begin{array}{l}\mathbf{3 6} \pm 4.2 \\
50 \%\end{array}$ & $\begin{array}{l}33 \pm 5 \\
34 \%\end{array}$ \\
\hline & Manual & No & $\mathrm{P}_{-}$ & $24 \pm 4.7$ & $\begin{array}{l}34 \pm 4.8 \\
39 \%\end{array}$ & $\begin{array}{l}\mathbf{4 1} \pm 5.1 \\
68 \%\end{array}$ & $\begin{array}{l}37 \pm 5.4 \\
54 \%\end{array}$ \\
\hline \multirow[t]{4}{*}{ Late } & Manual & Yes & $\mathrm{P}+$ & $\mathbf{2 0} \pm 4.5$ & $\begin{array}{l}\mathbf{2 4} \pm 4 \\
22 \%\end{array}$ & $\begin{array}{l}\mathbf{2 5} \pm 4.4 \\
24 \%\end{array}$ & $\begin{array}{l}\mathbf{2 5} \pm 3.8 \\
25 \%\end{array}$ \\
\hline & Mechanical & Yes & $\mathrm{P}_{-}$ & $\mathbf{1 5} \pm 4.3$ & $\begin{array}{l}\mathbf{2 1} \pm 3.8 \\
38 \%\end{array}$ & $\begin{array}{l}\mathbf{2 0} \pm 5 \\
32 \%\end{array}$ & $\begin{array}{l}\mathbf{1 7} \pm 4.6 \\
10 \%\end{array}$ \\
\hline & Manual & No & $\mathrm{P}+$ & $23 \pm 4.5$ & $\begin{array}{l}\mathbf{2 5} \pm 4.1 \\
15 \%\end{array}$ & $\begin{array}{l}25 \pm 4.8 \\
10 \%\end{array}$ & $\begin{array}{l}\mathbf{2 8} \pm 4.5 \\
26 \%\end{array}$ \\
\hline & Manual & No & $\mathrm{P}_{-}$ & $23 \pm 4.5$ & $\begin{array}{l}\mathbf{2 8} \pm 4.8 \\
28 \%\end{array}$ & $\begin{array}{l}\mathbf{2 9} \pm 3.6 \\
27 \%\end{array}$ & $\begin{array}{l}30 \pm 4.2 \\
33 \%\end{array}$ \\
\hline
\end{tabular}
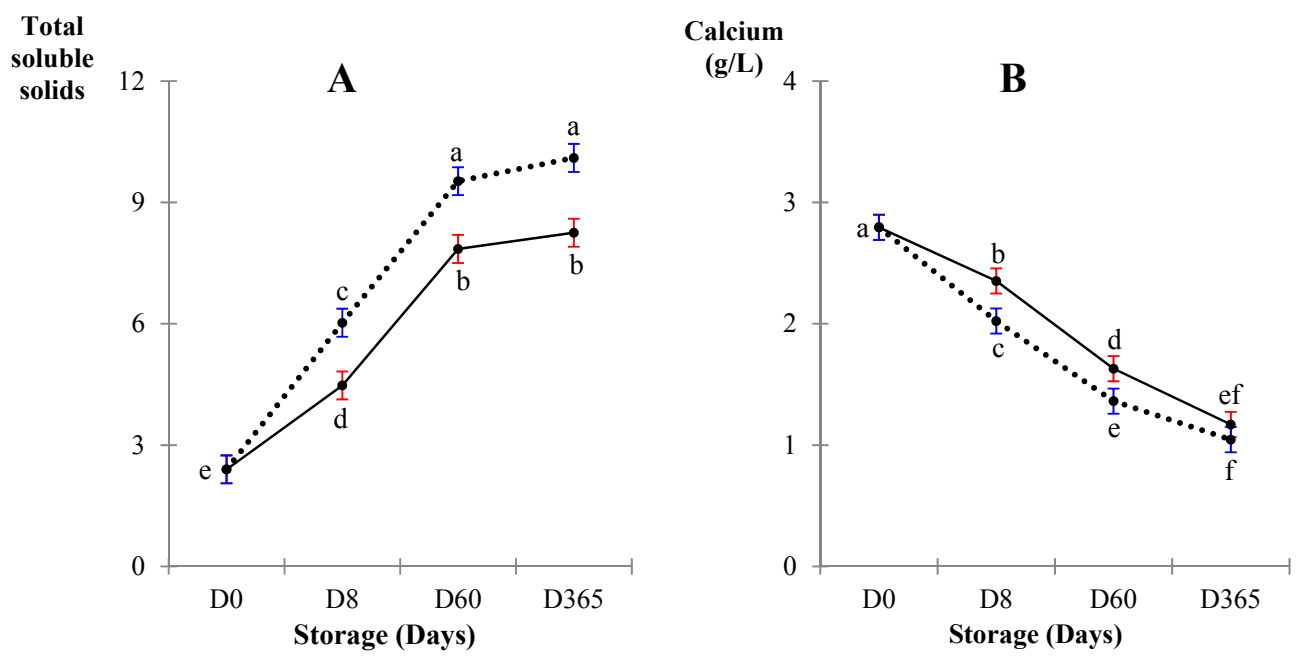

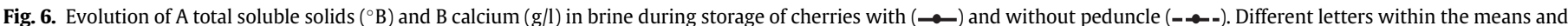
standard deviation of each date signify statistical separation at $\mathrm{P} \leq 0.05$.

firmness and use of both can lead to competition between them in the cross-linked de-esterified pectin thereby weakening the pectincalcium-based network.

Further, Taillan et al. (1992) demonstrated that residual pectin methyl esterase (PME) activity is present during brine storage of cherry fruit, and that calcium concentration modulates the stimulation of PME activity. The pedicel-abscission zone allowed an earlier transfer of brine components thus potentially enhancing the PME-calcium interaction and conferring improved texture. In contrast, the removal of $\mathrm{Ca}^{2+}$ bound to middle lamella-cell wall material enhances the rate and magnitude of galacturonan degradation by polygalacturonase (Buescher \& Hobson, 1982), and may cause softening. Loss of textural integrity can be controlled by the formation of intermolecular links between $\mathrm{Ca}^{2+}$ and pectin achieved by the addition of calcium salts (Barrett, Garcia, \& Wayne, 1998) and/or boosting the endogenous PME activity (Anthon, Blot, \& Barrett, 2005). The positive impact of peduncle removal observed in our conditions might thus be due to increased and accelerated calcium availability for pectin cross-linking in the cherry fleshy tissues.

\subsection{Microscopy}

Cytohistological observations were performed by light microscopy to better understand the impact of the studied harvest conditions on cherry fleshy tissues during brining. Applied to all conditions, this approach globally revealed that brined fruits display similar tendencies of cell and tissue structural behaviour. These tendencies will be described here taking as example sections of tissue fragments excised from fruits harvested mechanically (without peduncle) at early stage, and brined either for 2 or 12 months. Fig. 7 presents typical micrographs illustrating main changes in comparison with samples from fresh fruits.

In fresh fruits, the peripheral pericarp tissues showed cohesive, normally shaped cells exhibiting intact cell walls (Fig. 7A). In contrast, middle mesocarp and to a greater extent inner mesocarp tissues displayed profound cytomorphological alterations characteristic of ripening cherries (Batisse et al. 1998). These mainly consisted of cell plasmolysis and cell wall loosening giving the cells a shrunk, distorted contour (Fig. 7B and C). The natural mechanisms of cherries maturation (Barrett \& Gonzalez, 1994) paired to mechanical harvesting may have caused cell wall alterations. After 2 
Exocarp
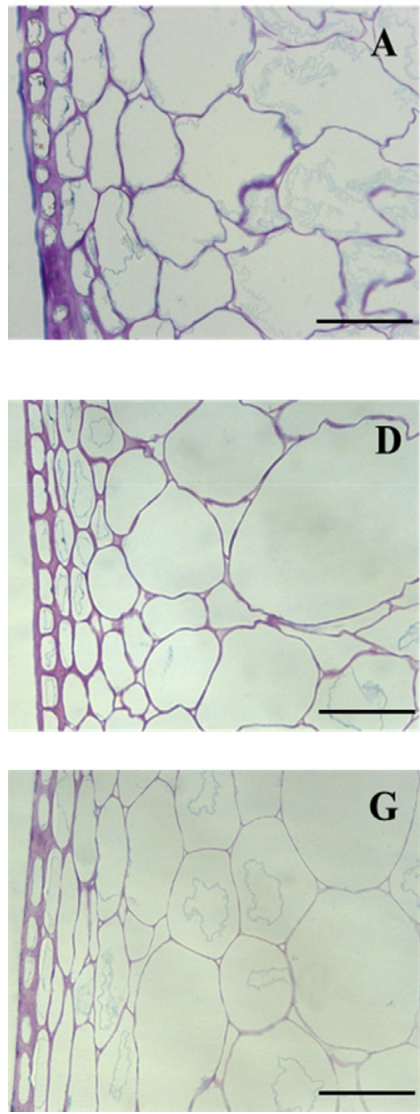

Middle mesocarp
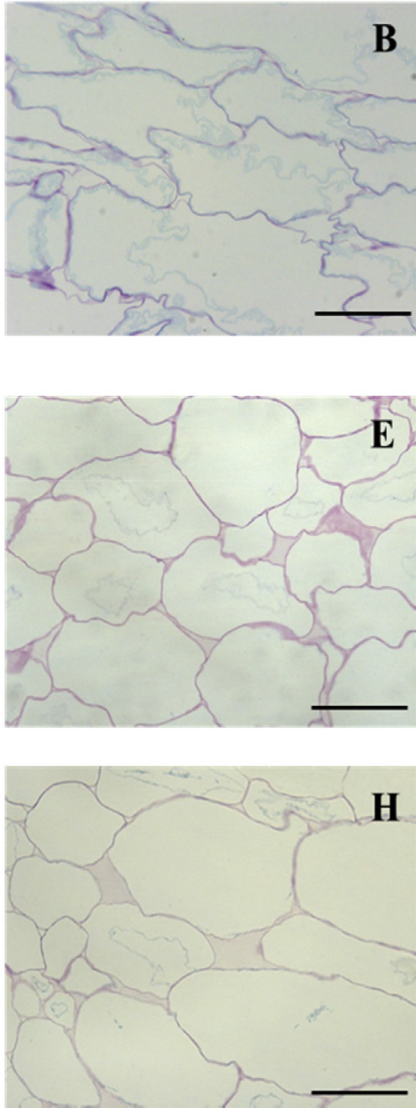

Deep mesocarp
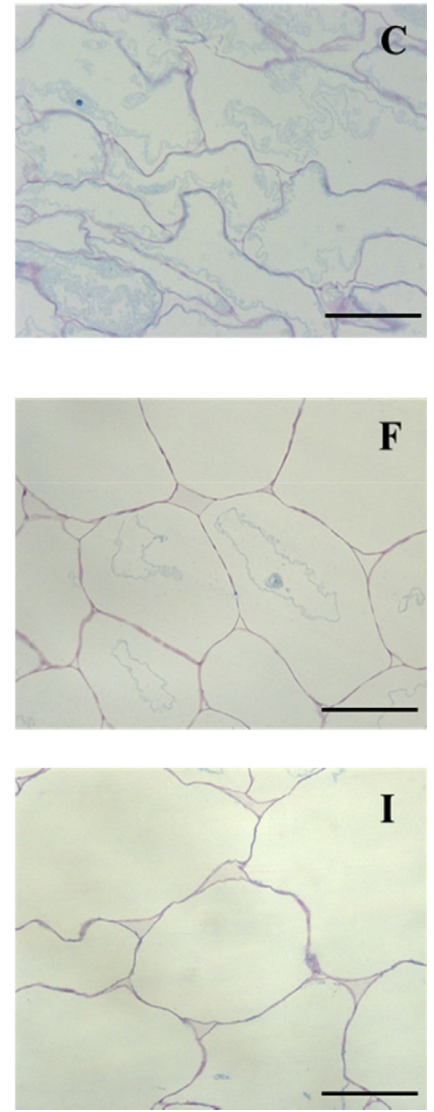

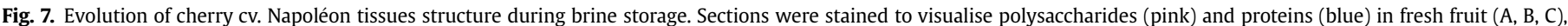

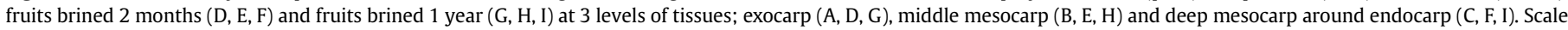
bars $=100 \mu \mathrm{m}$. (For interpretation of the references to colour in this figure legend, the reader is referred to the web version of this article.)

and 12 months in brine, the peripheral mesocarp cell layers appeared to be structurally similar to those of fresh fruits (compare Fig. 7A, D and G). But surprisingly, in middle and inner mesocarp, cells exhibited regular contour giving them a turgescent-like state (Fig. 7E, F, H and I). This apparent morphological rescue may be interpreted as cell wall stabilising effects of the brine via pectincalcium interactions. Alonso, Tortosa, Canet, and Rodríguez (2005) described a synergic effect of thermal treatment $\left(70{ }^{\circ} \mathrm{C}\right)$ and immersion in calcium solution to decrease the degree of esterification of water-soluble and EDTA-soluble pectins, thereby favouring the formation of calcium bridges and preventing the depolymerization of pectins in sweet cherry cv Pico Colorado. Other authors (Roy, Jauneau, \& Vian, 1994) observed high contents of non-esterified homogalacturonan sequences in the same spaces in accordance with the presence of calcium ions. Calcium pectate plays a role as a last barrier before total cell disaggregation and had an important function in maintaining firmness during brine storage. One-year storage in brine further consolidated the cellular architecture with an intercellular space rich in polysaccharides.

\section{Conclusion}

In this work, we characterized the different harvest factors involved in the evolution of cherries texture during brine storage. Overall, brine increased texture, thus alleviating slightly the initial damage due to harvest itineraries. Among these factors, ethephon treatment only impacted positively fresh fruit firmness and allowed to maintain acceptable cherries quality for processing over one year.

The harvest modalities that impacted texture of cherries were, in order of importance, harvest type, maturity stage, and presence of peduncle.

However, presence of an abscission zone accelerated osmotic exchange and also improved penetration of brine salts rate, conferring high texture gain with cell wall remodelling. Optimal textures were obtained for fruit harvested manually (to avoid mechanical damage) an early stage (to avoid over-ripening) and stored in brine without peduncle (to promote brine diffusion within fruit tissues). Since mechanical harvesting is unavoidable and fruit growers aim to shorten the harvest period, fruit quality enhancement may be established at post-harvest level. In addition to peduncle and its relevance for calcium diffusion, temperature and/ or pressure might modulate residual endogenous PME activity (Taillan et al. 1992). This leads to release a significant proportion of free carboxyl groups from pectin polymers that might then interact with calcium salt to form secondary cross-bridges thus improving cell wall strength, and consequently, a higher quality final product. This will be the object for further work.

\section{Acknowledgements}

The research was funded by research contracts $n^{\circ} 21000533$ and 
$\mathrm{n}^{\circ}$ C-14-PFL-06 between Aptunion and respectively INRA and Avignon University. ANRT partly covered the salary of authors WW under CIFRE grant n²013/0673.

\section{References}

Alonso, J., Tortosa, M. E., Canet, W., \& Rodríguez, M. T. (2005). Ultrastructural and changes in pectin composition of sweet cherry from the application of prefreezing treatments. Journal of Food Science-Chicago, 70(9), E526.

Anthon, G. E., Blot, L., \& Barrett, D. M. (2005). Improved firmness in calcified diced tomatoes by temperature activation of pectin methylesterase. Journal of Food Science, 70(5), C342-C347.

Athoo, T. O., Winkler, A., \& Knoche, M. (2015). Pedicel transpiration in sweet cherry fruit: Mechanisms, pathways, and factors. Journal of the American Society for Horticultural Science, 140(2), 136-143.

Atkinson, F., \& Strachan, C. (1962). Sulphur dioxide preservation of fruits. Summerland research station. Canada: Department of Agriculture. SP 28(200).

Barrett, D. M., Garcia, E., \& Wayne, J. E. (1998). Textural modification of processing tomatoes. Critical Reviews in Food Science and Nutrition, 38(3), 173-258.

Barrett, D. M., \& Gonzalez, C. (1994). Activity of softening enzymes during cherry maturation. Journal of Food Science, 59(3), 574-577.

Batisse, C., Coulomb, C., Coulomb, P. J., \& Buret, M. (1998). Cytological study of the effect of ethephon on Bigarreau-Napoleon cherries. Canadian Journal of BotanyRevue Canadienne de Botanique, 76(3), 547-551.

Batisse, C., Filslycaon, B., \& Buret, M. (1994). Pectin changes in ripening cherry fruit. Journal of Food Science, 59(2), 389-393.

Bell, T. A., \& Etchells, J. L. (1961). Influence of salt ( $\mathrm{NaCl})$ on pectinolytic softening of cucumbers. Journal of Food Science, 26(1), 84-90.

Brummell, D. A., \& Harpster, M. H. (2001). Cell wall metabolism in fruit softening and quality and its manipulation in transgenic plants. Plant Molecular Biology, $47(1-2), 311-340$.

Buescher, R., \& Hobson, G. (1982). Role of calcium and chelating agents in regulating the degradation of tomato fruit tissue by polygalacturonase. Journal of Food Biochemistry, 6(3), 147-160.

Cheol, C., Toivonen, P., Wiersma, P. A., \& Kappel, F. (2002). Differences in levels of pectic substances and firmness in fruit from six sweet cherry genotypes. Journal American Pomological Society, 56(4), 197-201.

Drake, S., \& Elfving, D. (2002). Indicators of maturity and storage quality of lapins' sweet cherry. HortTechnology, 12(4), 687-690.

Dupuy, P. (1959). L'Inhibition par l'acide sulfureux de l'oxydation de l'éthanol par acetobacter rancens. Institut national de la recherche agronomique (Doctoral dissertation).

El Maâtaoui, M., \& Pichot, C. (1999). Nuclear and cell fusion cause polyploidy in the megagametophyte of common cypress, Cupressus sempervirens L. Planta, 208(3), 345-351.

Estornell, L. H., Agusti, J., Merelo, P., Talon, M., \& Tadeo, F. R. (2013). Elucidating mechanisms underlying organ abscission. Plant Science, 199-200, 48-60.

Filslycaon, B., \& Buret, M. (1990). Loss of firmness and changes in pectic fractions during ripening and overripening of sweet cherry. Hortscience, 25(7), 777-778.

Garcia, P., Brenes, M., \& Garrido, A. (1994). Effects of pH and salt on the firmness of canned ripe olives. Sciences des Aliments, 14(2), 159-172.

Grotte, M., Duprat, F., Loonis, D., \& Pietri, E. (2001). Mechanical properties of the skin and the flesh of apples. International Journal of Food Properties, 4(1), $149-161$.

Hall, B. P., Shakeel, S. N., \& Schaller, G. E. (2007). Ethylene receptors: Ethylene perception and signal transduction. Journal of Plant Growth Regulation, 26(2), $118-130$.

Howard, L. R., \& Buescher, R. W. (1990). Cell-wall characteristics and firmness of fresh pack cucumber pickles affected by pasteurization and calcium-chloride. Journal of Food Biochemistry, 14(1), 31-43.

Hudson, J. M., \& Buescher, R. W. (1985). Pectic substances and firmness of cucumber pickles as influenced by $\mathrm{CaCl}_{2}, \mathrm{NaCl}$ and brine storage. Journal of Food Biochemistry, 9(3), 211-229.

Julien, H. (1972). Methode de conserve des cerises par l'anhydride sulfureux. Industries
Alimentaires et Agricoles (Doctoral dissertation).

Karel, M. (1975). Osmotic drying. FENNEMA, O. Principles of Food Science. New York: [sn], part 2: 348-357.

Khalid, S. A., Gellert, M., Szendrei, K., \& Duddeck, H. (1989). Prunetin 5-0-beta-dglucopyranoside, an isoflavone from the peduncle of Prunus avium and Prunus cerasus. Phytochemistry, 28(5), 1560-1561.

Mahajan, B. V. C., Gagandeep, S., \& Dhatt, A. S. (2008). Studies on ripening behaviour and quality of winter guava with ethylene gas and ethephon treatments. Journal of Food Science and Technology-Mysore, 45(1), 81-84.

McFeeters, R. F. (1985). Pectin methylation changes and calcium-ion effects in fermented and acidified cucumbers. Abstracts of Papers of the American Chemical Society 189(APR-): 39-AGFD.

Miller, C. H., \& Lower, R. L. (1972). Effect of ethephon on fresh-pack and brined cucumbers. Hortscience, 7(4), 418-420.

Missang, C. E., Maingonnat, J. F., Renard, C., \& Audergon, J. M. (2011). Texture variation in apricot: Intra-fruit heterogeneity, impact of thinning and relation with the texture after cooking. Food Research International, 44(1), 46-53.

Ozcan, M., \& Akgul, A. (1999). Storage quality in different brines of pickled capers (Capparis spp.). Grasas Y Aceites, 50(4), 269-274.

Payne, C. H., Beavers, D. V., Cain, R. F., \& Station, O. (1969). The chemical and preservative properties of sulfur dioxide solution for brining fruit. Agricultural Experiment Station. Oregon State University.

Richardson, D. G., Stebbins, R. L., Kirk, D., Booster, D., Jensen, L., \& Cain, R. (1998). Brining cherry mechanical harvest: Fruit maturity and machine factors involved in stem retention and bruising. Acta Horticulturae, 741-746.

Roy, S., Jauneau, A., \& Vian, B. (1994). Analytical detection of calcium ions and immunocytochemical visualization of homogalacturonic sequences in the ripe cherry tomato. Plant Physiology and Biochemistry, 32(5), 633-640.

Sekse, L., \& Lyngstad, L. (1993). Strategies for maintaining high quality in sweet cherries during harvesting, handling and marketing. II International Cherry Symposium. 410, 351-356.

Smith, E., \& Whiting, M. D. (2007). New developments toward mechanized sweet cherry harvest. HortScience, 2(4), 880.

Smith, E., \& Whiting, M. (2009). Effect of ethephon on sweet cherry pedicel-fruit retention force and quality is cultivar dependent. Plant Growth Regulation, 60(3), 213-223.

Taillan, E. (1991). Les matières pectiques et les phénomènes d'échanges au cours de la conservation et du confisage du bigarreau Napoléon (Prunus avium L.). Doctoral dissertation. Toulouse: Institut Polytechnique. Institut Polytechnique: 145.

Taillan, E., Ambid, C., Pech, J. C., \& Raynal, J. (1992). Demethylation of pectic substances-relationship to methylesterase activity during brine storage of cherries. Journal of Food Science, 57(3), 682-685.

Tang, H. C. L., \& McFeeters, R. F. (1983). Relationships among cell-wall constituents calcium and texture during cucumber fermentation and storage. Journal of Food Science, 48(1), 66-70.

Timm, E. J., \& Guyer, D. E. (1998). Tart cherry firmness and quality changes during mechanical harvesting and handling. Applied Engineering in Agriculture, 14(2), $153-158$.

Van Buren, J. (1979). The chemistry of texture in fruits and vegetables. Journal of Texture Studies, 10(1), 1-23.

Vashisth, T., \& Malladi, A. (2013). Fruit detachment in rabbiteye blueberry: Abscission and physical separation. Journal of the American Society for Horticultural Science, 138(2), 95-101.

Wani, A. A., Singh, P., Gul, K., Wani, M. H., \& Langowski, H. (2014). Sweet cherry (Prunus avium): Critical factors affecting the composition and shelf life. Food Packaging and Shelf Life, 1(1), 86-99.

Wei, J. M., Qi, X. D., Guan, J. F., \& Zhu, X. Q. (2011). Effect of cold storage and 1-MCP treatment on postharvest changes of fruit quality and cell wall metabolism in sweet cherry. Journal of Food Agriculture \& Environment, 9(3-4), 118-122.

Yamaguchi, M., Hughes, D. L., Tyler, K. B., Johnson, H., \& May, D. (1977). Preharvest ethephon application reduces muskmelon quality. Hortscience, 12(4), 324-325.

Zhang, L. H., Li, S. F., Liu, X. H., Song, C. L., \& Liu, X. (2012). Effects of ethephon on physicochemical and quality properties of kiwifruit during ripening. Postharvest Biology and Technology, 65, 69-75. 